\title{
Asymmetric Responses of Primary Productivity to Altered Precipitation Simulated by Ecosystem Models across Three Long- term Grassland Sites
}

\author{
Donghai Wu et al. \\ Correspondence to: Donghai Wu (donghai.wu@pku.edu.cn)
}

Supporting information captions (Figure S1-S9, Table S1-S14)

Figure S1 Comparison of parameters $(a$ and $b$ ) of fitted Eq. (1) for simulated annual GPP and NPP response to altered precipitation across models at the three sites (STU, KNZ and SGS).

Figure S2 Comparison of parameters ( $a$ and $b$ ) of fitted Eq. (1) for simulated annual ANPP and BNPP response to altered precipitation across models at the three sites (STU, KNZ and SGS).

Figure S3 Relationships between GPP (a), NPP (b), ANPP (c) and BNPP (d) and precipitation (P) derived from multi-year simulations. In each figure, SGS, KNZ and STU are from dry to moist. Temporal slopes are site based and relate inter-annual variability in precipitation to inter-annual variability in the productivities.

Figure S4 Magnitude of relative GPP (a), NPP (b), ANPP (c) and BNPP (d) pulses (P) and declines (D) in the wet years and the dry years at the three sites (SGS, KNZ and STU). Grey bars show median value of models, and black pentagrams in (c) represent relative changes from observation.

Figure S5 Responses of annual, growing season (GS, April-October) and non-growing season (non-GS, November-March) surface soil moisture content (SSWC, converted to $0-20 \mathrm{~cm}$ depth from reported soil layers) to altered precipitation (P) simulated by ecosystem models at STU, KNZ and SGS. The black line show median value of models, and filled area represents uncertainty from median absolute deviation. The grey dash line represents ambient precipitation.

Figure S6 Responses of annual, growing season (GS, April-October) and non-growing season (non-GS, November-March) total soil moisture content (TSWC, for full modeled depth) to altered precipitation (P) simulated by ecosystem models at STU, KNZ and SGS. The black line show median value of models, and filled area represents uncertainty from median absolute deviation. The grey dash line represents ambient precipitation.

Figure S7 Responses of simulated annual GPP (a), NPP (b), ANPP (c) and BNPP (d) to altered precipitation (P) levels at STU. Model ensemble of primary productivities for carbon-nitrogen $(\mathrm{C}-\mathrm{N})$ models and carbon-only models are respectively showed 
with solid and dashed lines. The fitted equation is Eq. (1). The grey dashed line represents ambient precipitation.

Figure S8 Responses of simulated annual GPP (a), NPP (b), ANPP (c) and BNPP (d) to altered precipitation (P) levels at KNZ. Model ensemble of primary productivities for carbon-nitrogen (C-N) models and carbon-only models are respectively showed with solid and dashed lines. The fitted equation is Eq. (1). The grey dashed line represents ambient precipitation.

Figure S9 Responses of simulated annual GPP (a), NPP (b), ANPP (c) and BNPP (d) to altered precipitation (P) levels at SGS. Model ensemble of primary productivities for carbon-nitrogen (C-N) models and carbon-only models are respectively showed with solid and dashed lines. The fitted equation is Eq. (1). The grey dashed line represents ambient precipitation.

Table S1 Summary of simulated processes for grasslands in the ecosystem models used in this study.

Table S2 Descriptions of N cycle in ecosystem models.

Table S3 Descriptions of P cycle in ecosystem models.

Table S4 Descriptions of C allocation scheme in ecosystem models.

Table S5 Descriptions of carbohydrate reserves in ecosystem models.

Table S6 Descriptions of leaf photosynthesis including water stress in ecosystem models.

Table S7 Descriptions of stomatal conductance including water stress in ecosystem models.

Table S8 Descriptions of scaling of photosynthesis from leaf to canopy in ecosystem models.

Table S9 Descriptions of phenology in ecosystem models.

Table S10 Descriptions of mortality in ecosystem models.

Table S11 Descriptions of soil hydrology in ecosystem models.

Table S12 Descriptions of surface energy budget in ecosystem models.

Table S13 Descriptions of root profile and dynamics in ecosystem models.

Table S14 Descriptions of grassland species in ecosystem models. 

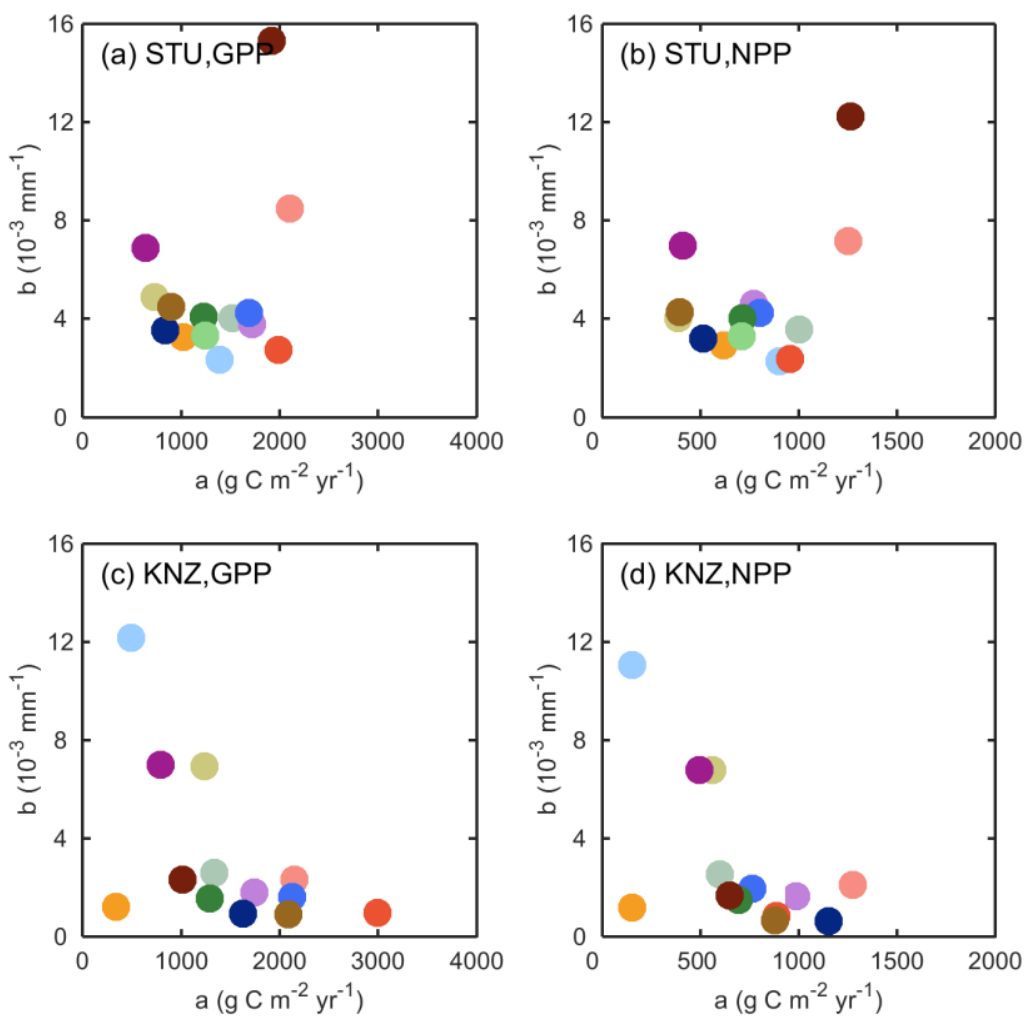

CABLE

CLM45-ORNL

DLEM

DOS-TEM

JSBACH

JULES

LPJ-GUESS

LPJmL-V3.5

ORCHIDEE-2

ORCHIDEE-11

- T\&C

- TECO

TRIPLEX-GHG
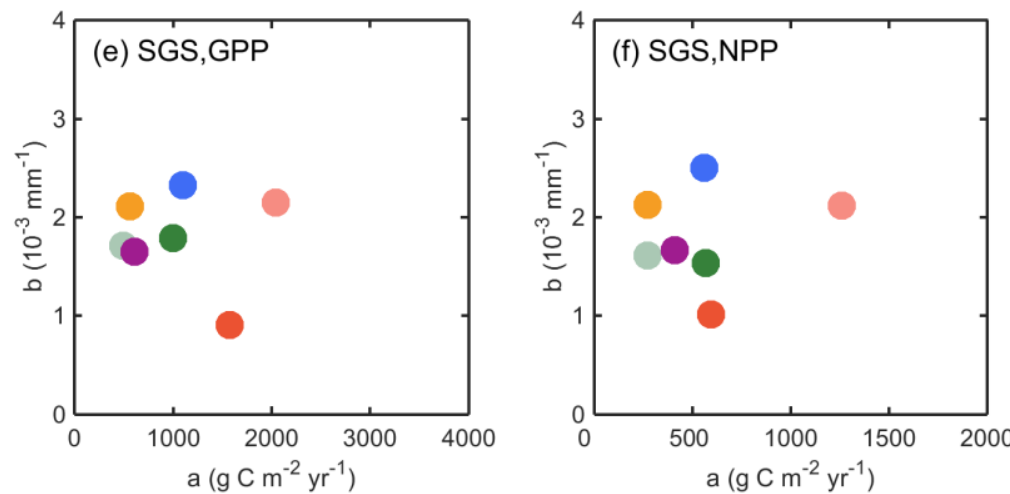

VISIT

Figure S1 Comparison of parameters $(a$ and $b$ ) of fitted Eq. (1) for simulated annual GPP and NPP response to altered precipitation across models at the three sites (STU, KNZ and SGS). 

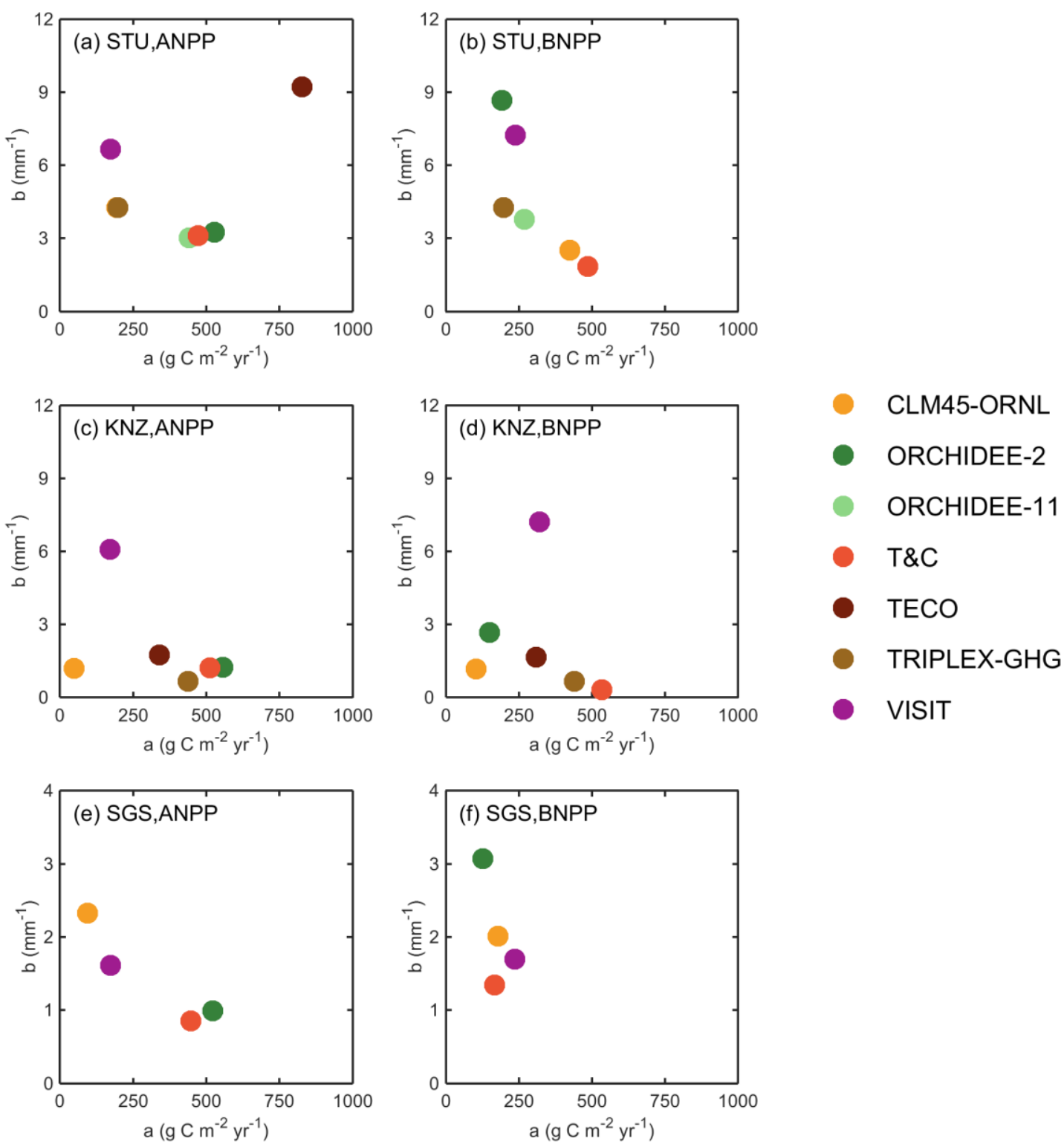

Figure S2 Comparison of parameters ( $a$ and $b$ ) of fitted Eq. (1) for simulated annual ANPP and BNPP response to altered precipitation across models at the three sites (STU, KNZ and SGS). 

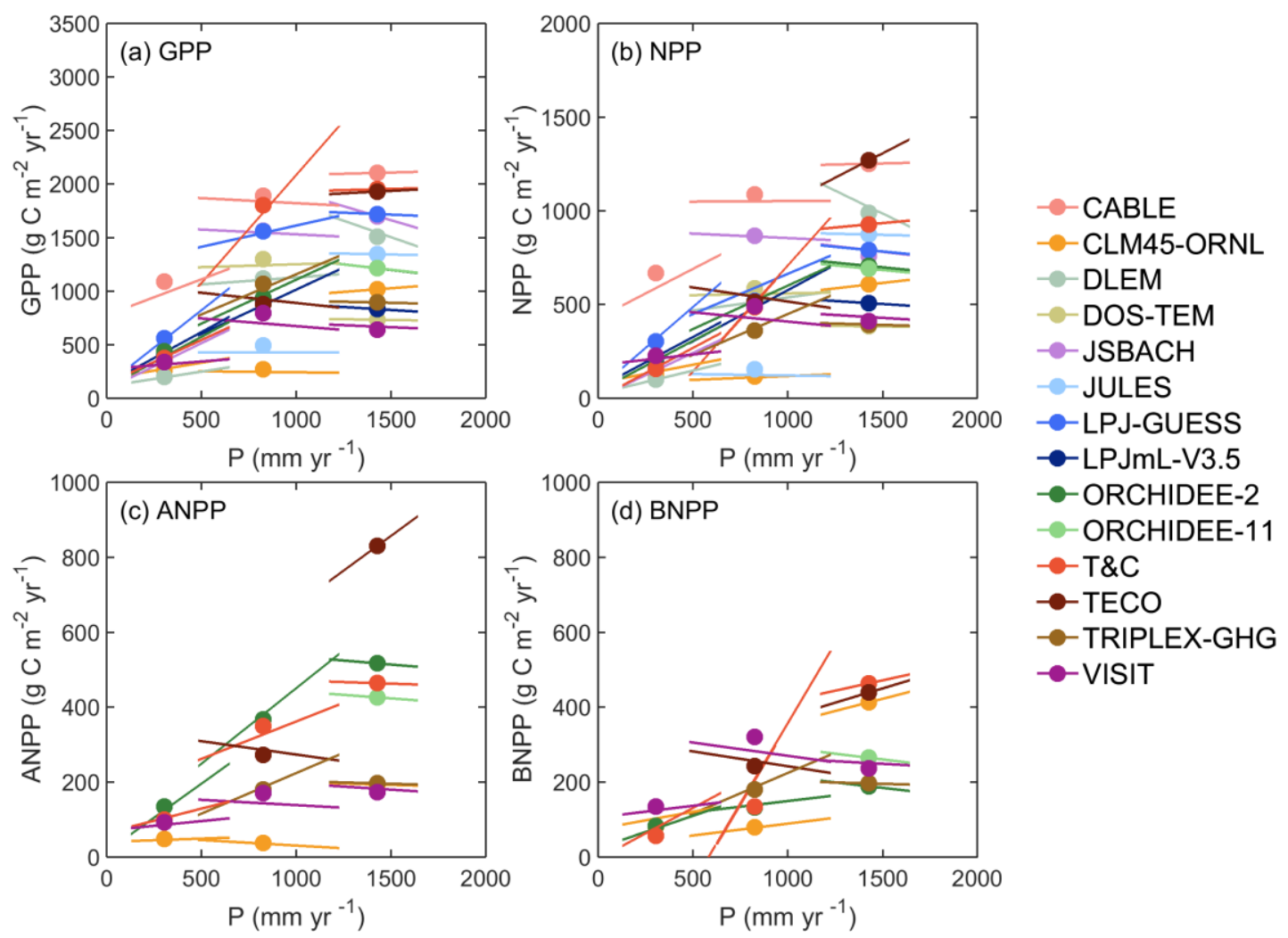

Figure S3 Relationships between GPP (a), NPP (b), ANPP (c) and BNPP (d) and precipitation (P) derived from multi-year simulations. In each figure, SGS, KNZ and STU are from dry to moist. Temporal slopes are site based and relate inter-annual variability in precipitation to inter-annual variability in the productivities. 

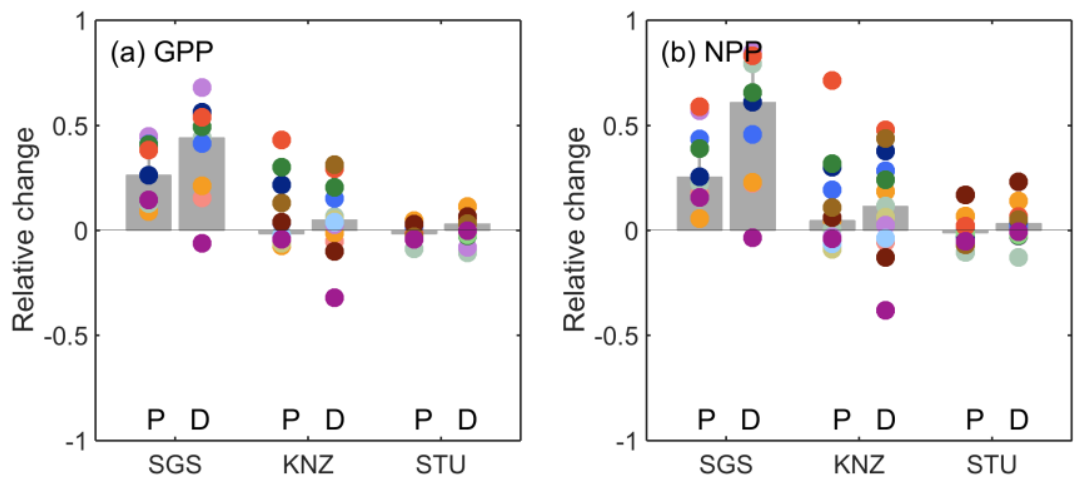

- CABLE

- CLM45-ORNL

- DLEM

DOS-TEM

- JSBACH

- JULES

- LPJ-GUESS

- LPJmL-V3.5
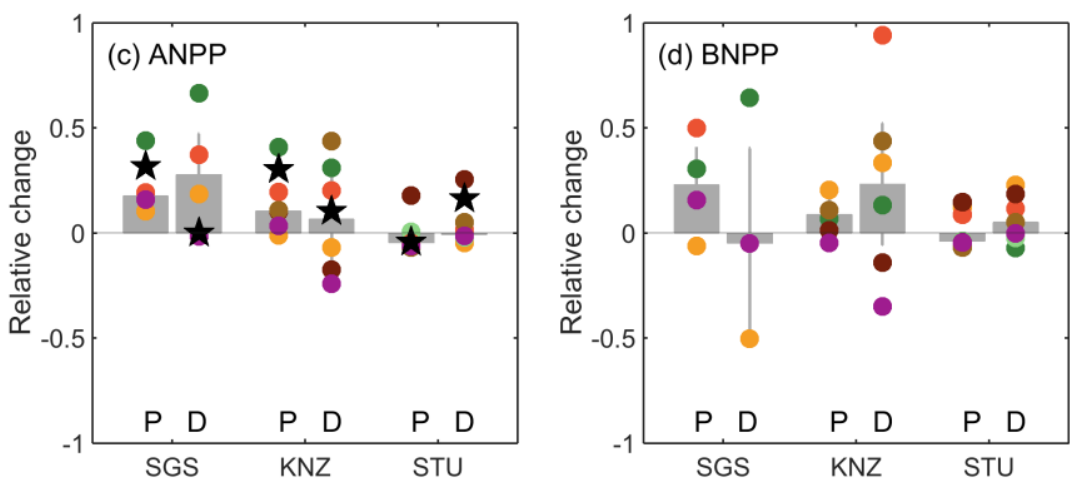

- ORCHIDEE-2

- ORCHIDEE-11

- T\&C

- TECO

- TRIPLEX-GHG

- VISIT

$\star$ observation

Figure S4 Magnitude of relative GPP (a), NPP (b), ANPP (c) and BNPP (d) pulses (P) and declines (D) in the wet years and the dry years at the three sites (SGS, KNZ and STU). Grey bars show median value of models, and black pentagrams in (c) represent relative changes from observation. 

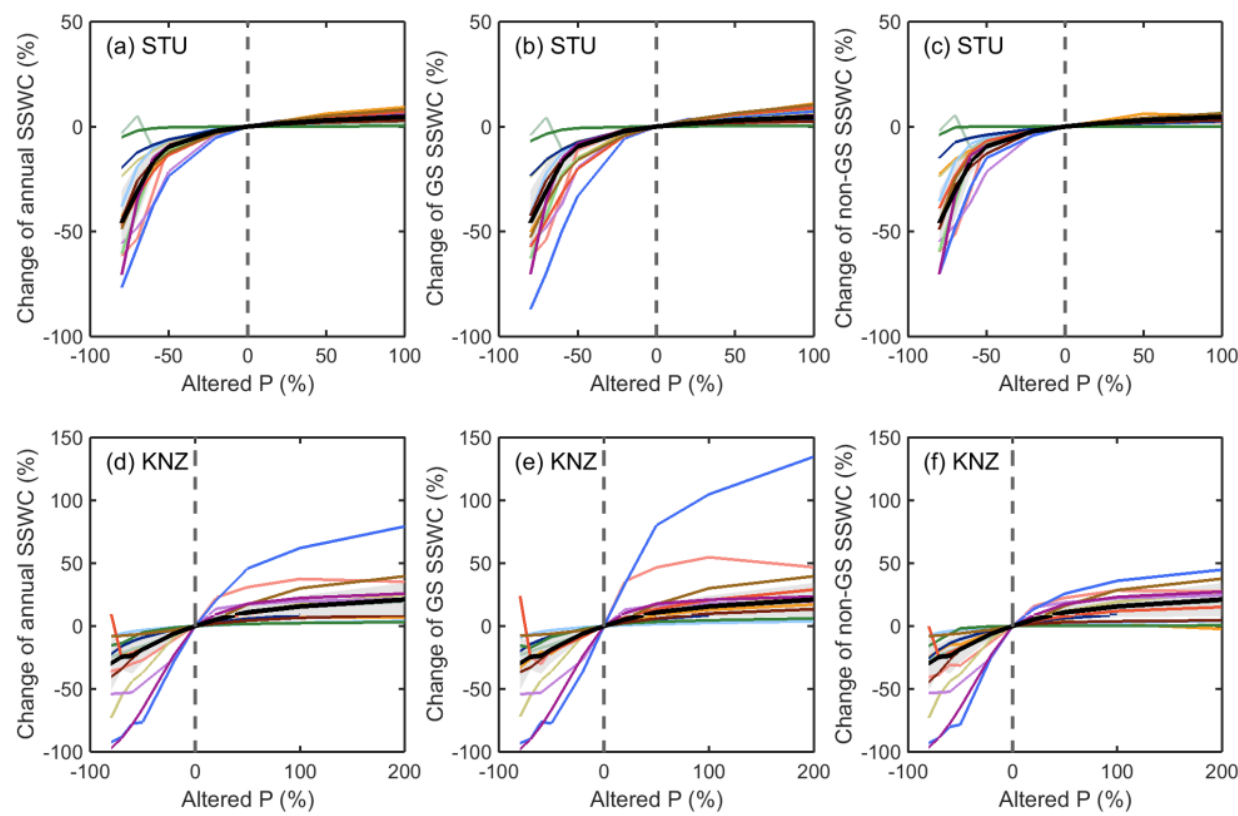

CABLE

CLM45-ORNL

DLEM

- DOS-TEM

JSBACH

- JULES

- LPJ-GUESS

LPJML-V3.5
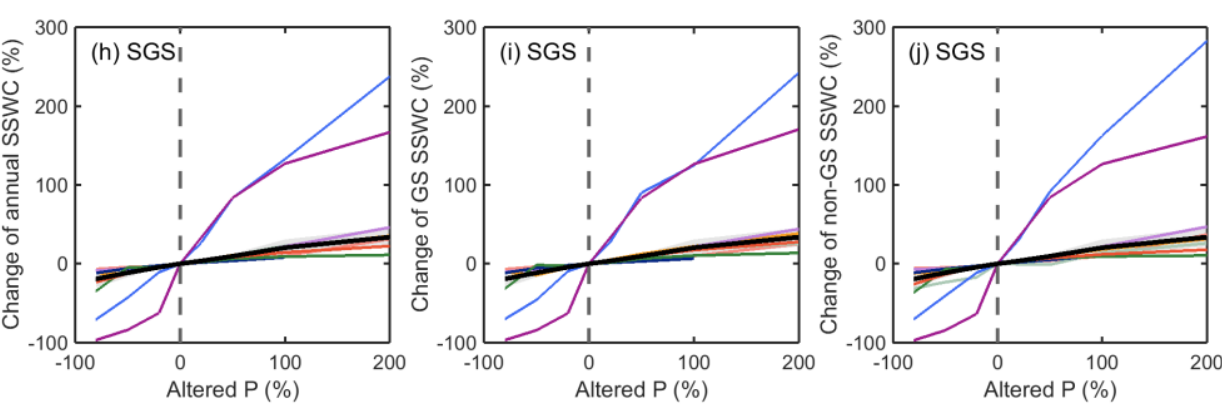

ORCHIDEE-2

ORCHIDEE-11

T\&C

TECO

-TRIPLEX-GHG

VISIT

ensemble

Figure S5 Responses of annual, growing season (GS, April-October) and non-growing season (non-GS, November-March) surface soil moisture content (SSWC, converted to $0-20 \mathrm{~cm}$ depth from reported soil layers) to altered precipitation (P) simulated by ecosystem models at STU, KNZ and SGS. The black line show median value of models, and filled area represents uncertainty from median absolute deviation. The grey dash line represents ambient precipitation. 

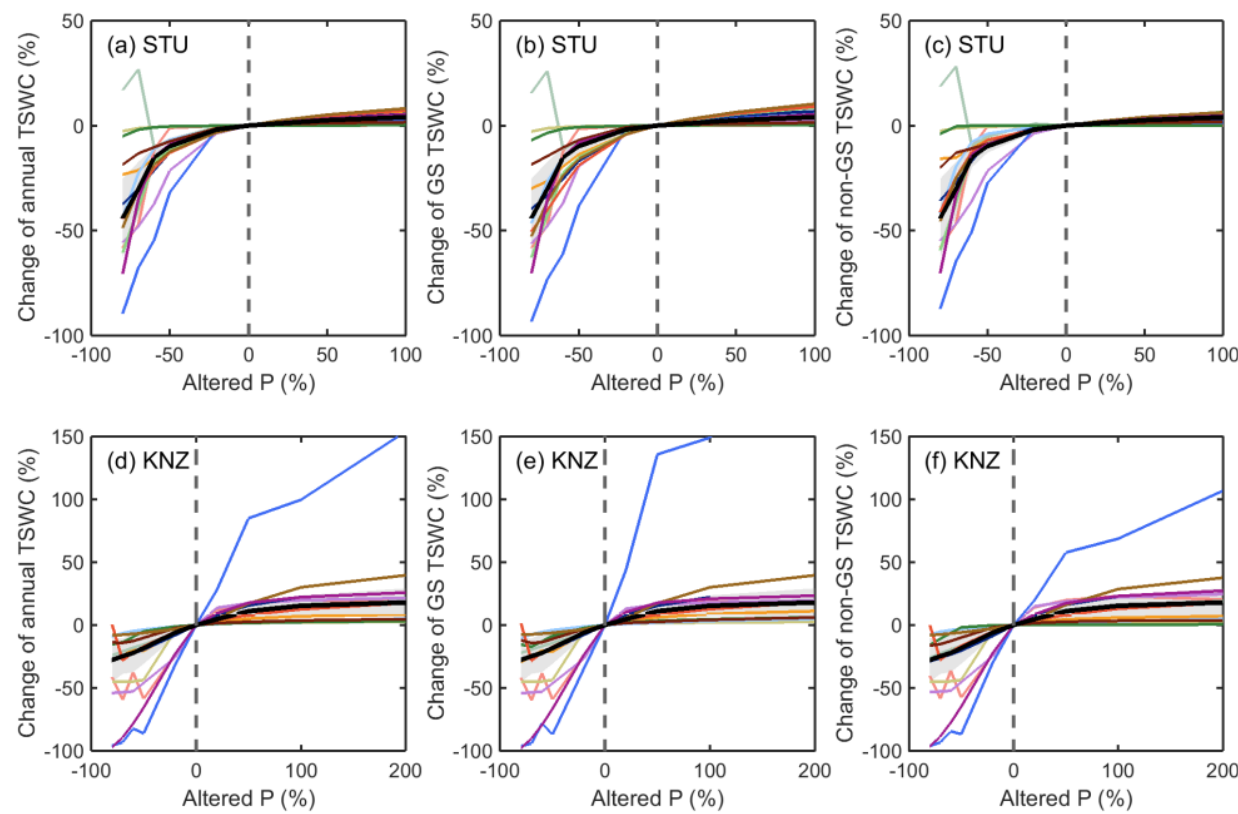

CABLE

CLM45-ORNL

DLEM

- DOS-TEM

JSBACH

- JULES

- LPJ-GUESS

LPJmL-V3.5
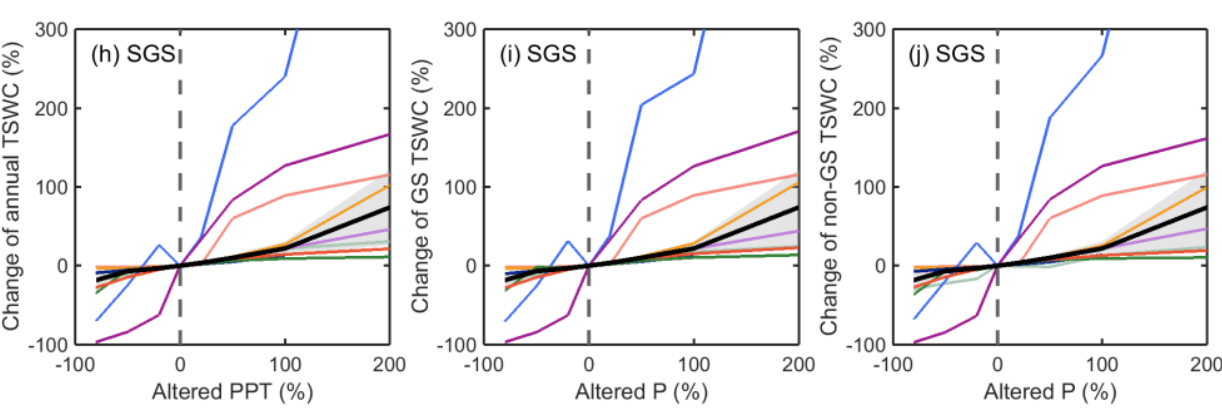

ORCHIDEE-2

ORCHIDEE-11

T\&C

TECO

-TRIPLEX-GHG

VISIT

ensemble

Figure S6 Responses of annual, growing season (GS, April-October) and non-growing season (non-GS, November-March) total soil moisture content (TSWC, for full modeled depth) to altered precipitation (P) simulated by ecosystem models at STU, KNZ and SGS. The black line show median value of models, and filled area represents uncertainty from median absolute deviation. The grey dash line represents ambient precipitation. 

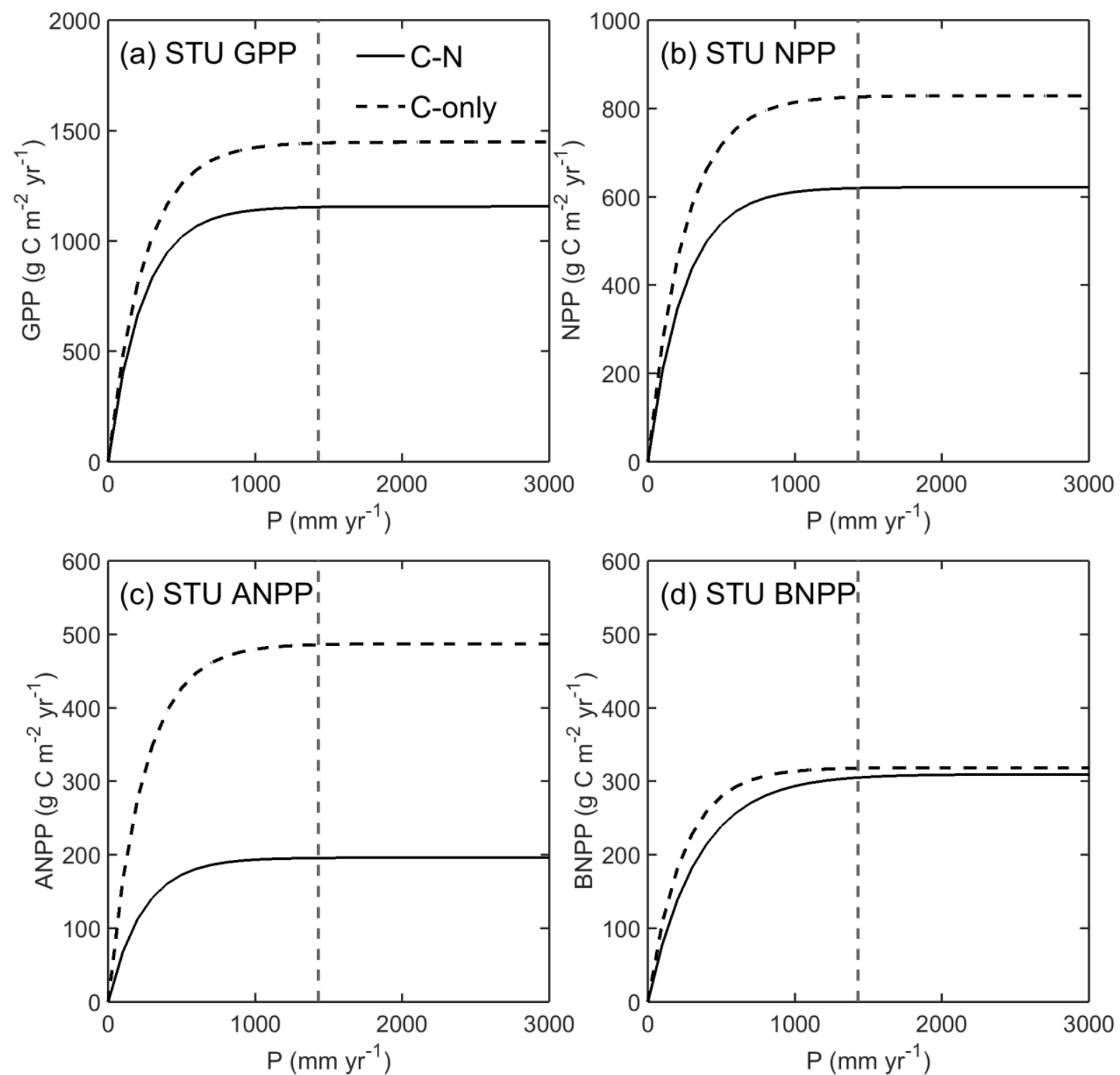

Figure S7 Responses of simulated annual GPP (a), NPP (b), ANPP (c) and BNPP (d) to altered precipitation (P) levels at STU. Model ensemble of primary productivities for carbon-nitrogen (C-N) models and carbon-only models are respectively showed with solid and dashed lines. The fitted equation is Eq. (1). The grey dashed line represents ambient precipitation. 

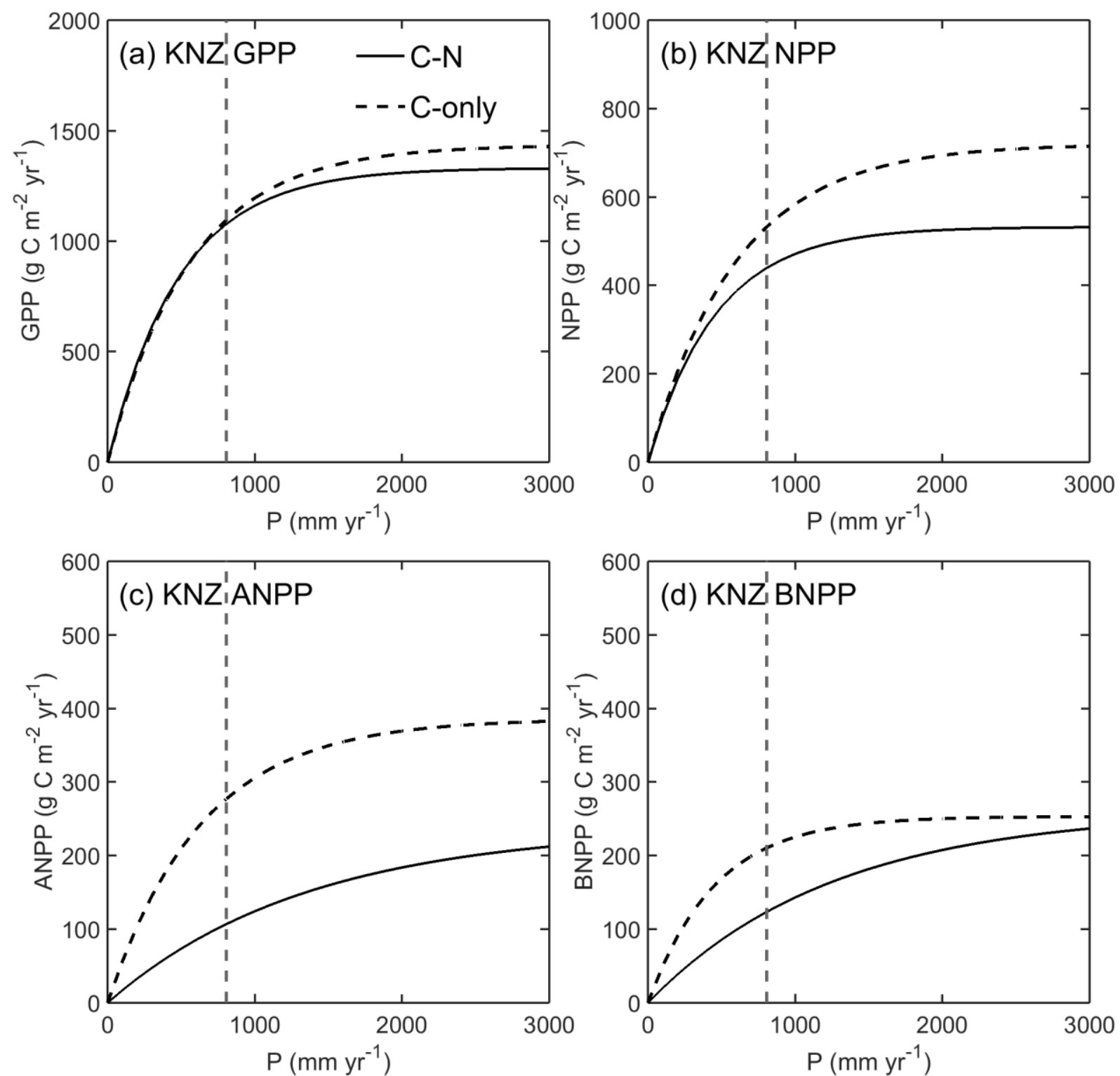

Figure S8 Responses of simulated annual GPP (a), NPP (b), ANPP (c) and BNPP (d) to altered precipitation (P) levels at KNZ. Model ensemble of primary productivities for carbon-nitrogen (C-N) models and carbon-only models are respectively showed with solid and dashed lines. The fitted equation is Eq. (1). The grey dashed line represents ambient precipitation. 

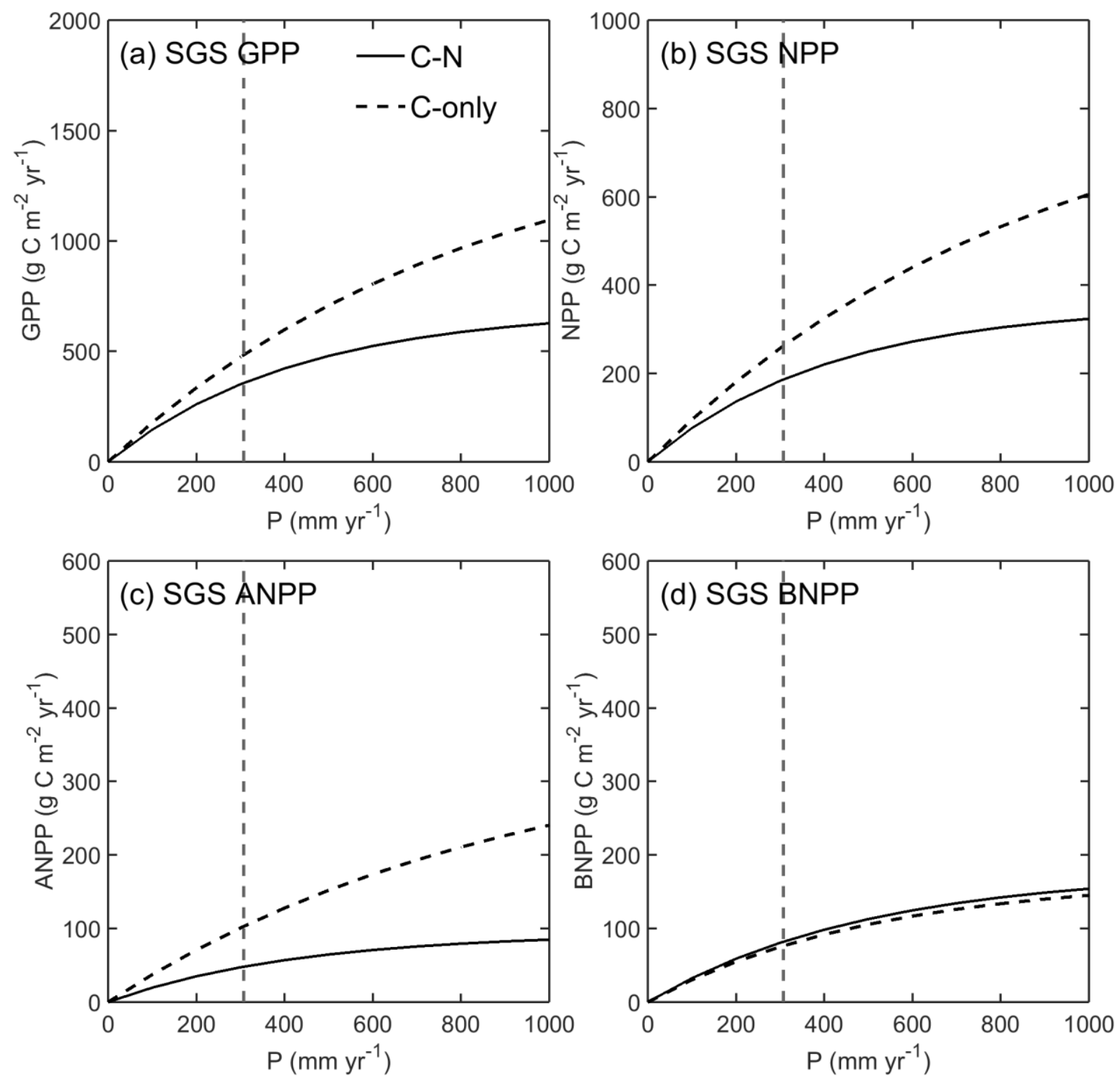

Figure S9 Responses of simulated annual GPP (a), NPP (b), ANPP (c) and BNPP (d) to altered precipitation (P) levels at SGS. Model ensemble of primary productivities for carbon-nitrogen (C-N) models and carbon-only models are respectively showed with solid and dashed lines. The fitted equation is Eq. (1). The grey dashed line represents ambient precipitation. 


\section{Supporting information: Table S1-S14}

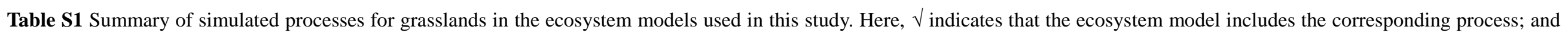

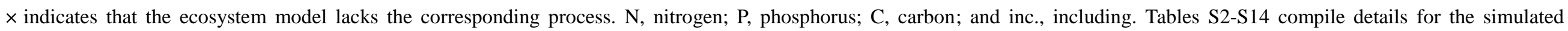
processes in each model. All process descriptions were contributed by the modelers.

\begin{tabular}{|c|c|c|c|c|c|c|c|c|c|c|c|c|c|}
\hline Model & $\begin{array}{c}\mathrm{N} \\
\text { cycle }\end{array}$ & $\begin{array}{c}\mathrm{P} \\
\text { cycle }\end{array}$ & $\begin{array}{c}\mathrm{C} \\
\text { allocatio } \\
\text { n scheme }\end{array}$ & $\begin{array}{c}\text { Carboh } \\
\text { ydrate } \\
\text { reserves }\end{array}$ & $\begin{array}{c}\text { Leaf } \\
\text { photosynt } \\
\text { hesis inc. } \\
\text { water } \\
\text { stress }\end{array}$ & $\begin{array}{c}\text { Stomatal } \\
\text { conductanc } \\
\text { e inc. } \\
\text { water } \\
\text { stress }\end{array}$ & $\begin{array}{c}\text { Scaling of } \\
\text { photosynth } \\
\text { esis from } \\
\text { leaf to } \\
\text { canopy }\end{array}$ & Phenology & Mortality & $\begin{array}{c}\text { Soil } \\
\text { hydrology }\end{array}$ & $\begin{array}{c}\text { Surface } \\
\text { energy } \\
\text { budget }\end{array}$ & $\begin{array}{c}\text { Root } \\
\text { profile and } \\
\text { dynamics }\end{array}$ & $\begin{array}{c}\text { Grassland } \\
\text { species }\end{array}$ \\
\hline CABLE & $x$ & $x$ & $\sqrt{ }$ & $\sqrt{ }$ & $\sqrt{ }$ & $\sqrt{ }$ & $\sqrt{ }$ & $\sqrt{ }$ & $\sqrt{ }$ & $\sqrt{ }$ & $\sqrt{ }$ & $\sqrt{ }$ & $\sqrt{ }$ \\
\hline CLM45-ORNL & $\sqrt{ }$ & $x$ & $\sqrt{ }$ & $\sqrt{ }$ & $\sqrt{ }$ & $\sqrt{ }$ & $\sqrt{ }$ & $\sqrt{ }$ & $\sqrt{ }$ & $\sqrt{ }$ & $\sqrt{ }$ & $\sqrt{ }$ & $\sqrt{ }$ \\
\hline DLEM & $\sqrt{ }$ & $x$ & $\sqrt{ }$ & $\sqrt{ }$ & $\sqrt{ }$ & $\sqrt{ }$ & $\sqrt{ }$ & $\sqrt{ }$ & $\sqrt{ }$ & $\sqrt{ }$ & $x$ & $\sqrt{ }$ & $\sqrt{ }$ \\
\hline DOS-TEM & $\sqrt{ }$ & $x$ & $\sqrt{ }$ & $x$ & $\sqrt{ }$ & $\sqrt{ }$ & $\sqrt{ }$ & $\sqrt{ }$ & $\sqrt{ }$ & $\sqrt{ }$ & $x$ & $\sqrt{ }$ & $\sqrt{ }$ \\
\hline JSBACH & $x$ & $x$ & $\sqrt{ }$ & $\sqrt{ }$ & $\sqrt{ }$ & $\sqrt{ }$ & $\sqrt{ }$ & $\sqrt{ }$ & $\sqrt{ }$ & $\sqrt{ }$ & $\sqrt{ }$ & $\sqrt{ }$ & $\sqrt{ }$ \\
\hline JULES & $x$ & $x$ & $\sqrt{ }$ & $x$ & $\sqrt{ }$ & $\sqrt{ }$ & $\sqrt{ }$ & $\sqrt{ }$ & $\sqrt{ }$ & $\sqrt{ }$ & $\sqrt{ }$ & $\sqrt{ }$ & $\sqrt{ }$ \\
\hline LPJ-GUESS & $\sqrt{ }$ & $x$ & $\sqrt{ }$ & $x$ & $\sqrt{ }$ & $\sqrt{ }$ & $\sqrt{ }$ & $\sqrt{ }$ & $\sqrt{ }$ & $\sqrt{ }$ & $x$ & $\sqrt{ }$ & $\sqrt{ }$ \\
\hline LPJmL-V3.5 & $x$ & $x$ & $\sqrt{ }$ & $x$ & $\sqrt{ }$ & $\sqrt{ }$ & $\sqrt{ }$ & $\sqrt{ }$ & $\sqrt{ }$ & $\sqrt{ }$ & $\sqrt{ }$ & $\sqrt{ }$ & $\sqrt{ }$ \\
\hline ORCHIDEE-2 & $x$ & $x$ & $\sqrt{ }$ & $\sqrt{ }$ & $\sqrt{ }$ & $\sqrt{ }$ & $\sqrt{ }$ & $\sqrt{ }$ & $\sqrt{ }$ & $\sqrt{ }$ & $\sqrt{ }$ & $\sqrt{ }$ & $\sqrt{ }$ \\
\hline ORCHIDEE-11 & $x$ & $x$ & $\sqrt{ }$ & $\sqrt{ }$ & $\sqrt{ }$ & $\sqrt{ }$ & $\sqrt{ }$ & $\sqrt{ }$ & $\sqrt{ }$ & $\sqrt{ }$ & $\sqrt{ }$ & $\sqrt{ }$ & $\sqrt{ }$ \\
\hline $\mathrm{T} \& \mathrm{C}$ & $x$ & $x$ & $\sqrt{ }$ & $\sqrt{ }$ & $\sqrt{ }$ & $\sqrt{ }$ & $\sqrt{ }$ & $\sqrt{ }$ & $\sqrt{ }$ & $\sqrt{ }$ & $\sqrt{ }$ & $\sqrt{ }$ & $\sqrt{ }$ \\
\hline TECO & $x$ & $x$ & $\sqrt{ }$ & $\sqrt{ }$ & $\sqrt{ }$ & $\sqrt{ }$ & $\sqrt{ }$ & $\sqrt{ }$ & $\sqrt{ }$ & $\sqrt{ }$ & $\sqrt{ }$ & $\sqrt{ }$ & $\sqrt{ }$ \\
\hline TRIPLEX-GHG & $\sqrt{ }$ & $x$ & $\sqrt{ }$ & $x$ & $\sqrt{ }$ & $\sqrt{ }$ & $\sqrt{ }$ & $\sqrt{ }$ & $\sqrt{ }$ & $\sqrt{ }$ & $\sqrt{ }$ & $\sqrt{ }$ & $\sqrt{ }$ \\
\hline VISIT & $x$ & $x$ & $\sqrt{ }$ & $\sqrt{ }$ & $\sqrt{ }$ & $\sqrt{ }$ & $\sqrt{ }$ & $\sqrt{ }$ & $\sqrt{ }$ & $\sqrt{ }$ & $\sqrt{ }$ & $\sqrt{ }$ & $\sqrt{ }$ \\
\hline
\end{tabular}


Table S2 Descriptions of N cycle in ecosystem models.

\begin{tabular}{|c|c|}
\hline Model & $\mathrm{N}$ cycle \\
\hline CABLE & Not used in this study. \\
\hline CLM45-ORNL & Yes \\
\hline DLEM & $\begin{array}{l}\mathrm{N} \text { cycle is fully open and considers external sources and sinks through deposition, leaching, nitrous gas emission and } \mathrm{N} \text { immobilization (Dangal et al., } 2016 \text {; Tian } \\
\text { et al., 2011). Available soil water content determines soil decomposition and } \mathrm{N} \text { mineralization, which ultimately affects soil } \mathrm{N} \text { availability. Soil } \mathrm{N} \text { availability in } \\
\text { turn regulates grassland productivity. }\end{array}$ \\
\hline DOS-TEM & $\begin{array}{l}\text { Yes, open } \mathrm{N} \text { cycle. } \mathrm{N} \text { loss from runoff and } \mathrm{N} \text { input from deposition. Soil } \mathrm{N} \text { availability is a function of } \mathrm{N} \text { input and } \mathrm{N} \text { loss, net mineralization and } \mathrm{N} \text { uptake. If } \mathrm{N} \\
\text { availability is limiting, it can down regulate gross primary productivity (GPP). }\end{array}$ \\
\hline JSBACH & Not in this model version. \\
\hline JULES & Not in this model version. \\
\hline LPJ-GUESS & Yes \\
\hline LPJmL-V3.5 & No \\
\hline ORCHIDEE-2 & No \\
\hline ORCHIDEE-11 & No \\
\hline $\mathrm{T} \& \mathrm{C}$ & No \\
\hline TECO & No \\
\hline TRIPLEX-GHG & Yes \\
\hline VISIT & No, VISIT has a $\mathrm{N}$ cycle scheme, but used only for $\mathrm{N}_{2} \mathrm{O}$ emission calculation; i.e., not coupled with $\mathrm{C}$ cycle. \\
\hline
\end{tabular}


Table S3 Descriptions of P cycle in ecosystem models.

\begin{tabular}{|c|c|}
\hline Model & P cycle \\
\hline CABLE & Not used in this study. \\
\hline CLM45-ORNL & No \\
\hline DLEM & No \\
\hline DOS-TEM & No \\
\hline JSBACH & No \\
\hline JULES & No \\
\hline LPJ-GUESS & No \\
\hline LPJmL-V3.5 & No \\
\hline ORCHIDEE-2 & No \\
\hline ORCHIDEE-11 & No \\
\hline $\mathrm{T} \& \mathrm{C}$ & No \\
\hline TECO & No \\
\hline TRIPLEX-GHG & No \\
\hline VISIT & No \\
\hline
\end{tabular}


Table S4 Descriptions of C allocation scheme in ecosystem models.

\begin{tabular}{|c|c|}
\hline Model & C allocation scheme \\
\hline CABLE & $\begin{array}{l}\text { Fraction of C allocated to above-ground and below-ground depends on leaf phenology that is divided into four phases, including leaf flushing phase (P1), steady leaf } \\
\text { growth phase (P2), leaf senescence (P3) and dormant phase (P4). During P1, } 80 \% \text { of NPP is allocated to leaves, and } 20 \% \text { to roots; during P2, 35\% is allocated to } \\
\text { leaves, and remaining to roots (there is no difference between C3 and C4 grasses in C allocation); and during P3, all NPP is allocated to roots. }\end{array}$ \\
\hline CLM45-ORNL & Fractional allocation to each plant component is constant in time, except stem to leaf ratio is a function of NPP. \\
\hline DLEM & $\begin{array}{c}\text { Allocation scheme is based on resource (light, water and N) (Friedlingstein et al., 1999). The allocation strategy is first confined by the scarcest resource and then } \\
\text { regulated by phenology. }\end{array}$ \\
\hline DOS-TEM & Allocation coefficients to leaves, wood and roots compartments are constant. \\
\hline JSBACH & $\begin{array}{l}\text { NPP enters the two vegetation } \mathrm{C} \text { pools used in JSBACH for grasses at fixed proportions: } 0.8 \text { to green (leaves and fine roots) and } 0.15 \text { to reserve (rest } 0.05 \text { directly } \\
\text { enters the soil as sugars to root exudates). C loss by grazing rate } \sim 0.00164 / \text { day } \mathrm{C}_{\text {green,grass. }}\end{array}$ \\
\hline JULES & Partitioning into 'spreading' and 'growth' based on leaf area index (LAI); and leaf:root:wood partitioning from allometric relationships. \\
\hline LPJ-GUESS & $\begin{array}{l}\text { Assimilated C remaining after accounting for respiration and allocation to reproduction is available for allocation to the living tissue compartments as new biomass } \\
\text { (Smith et al., 2001; Smith et al., 2014). Allocation is performed once per annual time step, and includes functional-balance response to water availability, i.e. } \\
\text { increased allocation to roots versus shoots under conditions of water stress. }\end{array}$ \\
\hline LPJmL-V3.5 & $\begin{array}{l}\text { Allocation is determined using pipe-model theory for woody vegetation and by a leaf-to-shoot ratio of } 0.75 \text { which is linearly modified by soil moisture stress (Sitch } \\
\text { et al., 2003). The annual C increment is allocated to leaves, fine roots and sapwood. }\end{array}$ \\
\hline ORCHIDEE-2 & Allocation scheme used an optimum allocation of resources to minimize limitation between light, water and nutrients (Friedlingstein et al., 1999). \\
\hline ORCHIDEE-11 & Same as ORCHIDEE-2 \\
\hline $\mathrm{T} \& \mathrm{C}$ & $\begin{array}{l}\text { C allocation is a dynamic process that accounts for resource availability (light and water) (Friedlingstein et al., 1999) and allometric constraints, e.g., a minimum } \\
\text { ratio of fine root to foliage C; and an upper limit for the storage of carbohydrate reserves. Patterns of plant allocation are also influenced by the phenological phase. } \\
\text { Five C pools are explicitly simulated for grass (leaves, fine roots, carbohydrate reserve, reproductive tissues, and standing dead leaves). }\end{array}$ \\
\hline TECO & $\begin{array}{l}\text { C is transferred from the canopy model to a non-structural carbon (NSC) pool. Allocation from NSC pool to stems, leaves and roots depends on growth rate, } \\
\text { phenology of vegetation, and size of the NSC. For grasslands, the root biomass is comprised solely of fine roots. Fine roots are split into } 10 \text { soil layers in the top } 190 \\
\qquad \mathrm{~cm} \text { of the soil. The first soil layer is } 10 \mathrm{~cm} \text { thick, and all others are } 20 \mathrm{~cm} \text { thick. }\end{array}$ \\
\hline TRIPLEX-GHG & Allocation coefficients were initiated as constant but altered dynamically based on limitation factor of soil mineral N. \\
\hline VISIT & Allocation scheme is based on optimal LAI and root/shoot allometry (Ito and Oikawa, 2002). \\
\hline
\end{tabular}


Table S5 Descriptions of carbohydrate reserves in ecosystem models.

\begin{tabular}{|c|c|}
\hline Model & Carbohydrate reserves \\
\hline CABLE & $\begin{array}{l}\text { Yes, carbohydrate reserves are used as a temporary storage for excessive } \mathrm{C} \text { that occurs when } \mathrm{N} \text { demand for a given net primary productivity (NPP) cannot be met by } \\
\text { available soil N. Carbohydrate reserves are not used for leaf flush or fruit growth, and it is consumed by maintenance respiration over time. }\end{array}$ \\
\hline CLM45-ORNL & Yes, carbohydrates reserves are transferred to all plant components at the beginning of season to initiate leaf area index (LAI) and photosynthesis. \\
\hline DLEM & Non-structural carbohydrate (NSC) pool transferred to leaves at the beginning of growing season. \\
\hline DOS-TEM & No carbohydrate pool. \\
\hline JSBACH & $\begin{array}{l}0.15 \text { of grass NPP goes to reserves which are used if } \mathrm{NPP}=0 \text {. Reserves are not used to initiate LAI. In the current JSBACH, LAI is not coupled to the available C } \\
\text { (but to shedding in case of NPP }=0 \text { which reduces the overall LAI). }\end{array}$ \\
\hline JULES & 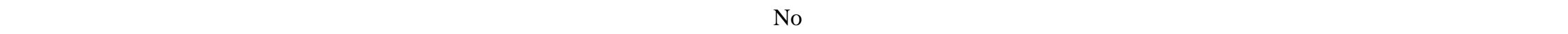 \\
\hline LPJ-GUESS & No \\
\hline LPJmL-V3.5 & No \\
\hline ORCHIDEE-2 & Yes, carbohydrates reserves are transferred to leaf biomass at the beginning of season to initiate LAI and photosynthesis. \\
\hline ORCHIDEE-11 & Same as ORCHIDEE-2 \\
\hline $\mathrm{T} \& \mathrm{C}$ & $\begin{array}{c}\mathrm{C} \text { can be allocated to reserves throughout the growing season and can be subsequently translocated to leaves and fine roots to favour leaf expansion at the onset of } \\
\text { the growing season or after severe disturbances. }\end{array}$ \\
\hline TECO & The NSC pool is carried over through winter months, and is used for green up the following spring. \\
\hline TRIPLEX-GHG & No specific NSC pools. \\
\hline VISIT & Yes, NSC pool transferred to leaves at the beginning of growing season. \\
\hline
\end{tabular}


Table S6 Descriptions of leaf photosynthesis including (inc.) water stress in ecosystem models.

Model

CABLE

CLM45-ORNL

DLEM

DOS-TEM

JSBACH

JULES

LPJ-GUESS

LPJmL-V3.5

ORCHIDEE-2

ORCHIDEE-11

$\mathrm{T} \& \mathrm{C}$

TECO

TRIPLEX-GHG VISIT
Leaf photosynthesis inc. water stress

Photosynthesis (A) is represented following the Farquhar model (Wang and Leuning, 1998); stomatal conductance ( $g_{s}$ ) is represented following (De Kauwe et al., 2015; Medlyn et al., 2011). Water stress is represented by an empirical relationship based on soil texture and limits the slope of the coupled relationship between A and $\mathrm{g}_{\mathrm{s}}$ (Eqn. A19) (Wang et al., 2011).

Water stress is calculated from soil water content from a predefined exponential root profile (plant function type - PFT - dependent), then applied to reduction of Vcmax on photosynthesis.

Leaf photosynthesis based on modified Farquhar's model (Farquhar et al., 1980). Water related stress on photosynthesis is estimated as a function of soil moisture content in different soil layers (10 soil layers) and PFT dependent vertical root distribution.

GPP is affected by water stress through the effect of evapotranspiration (estimated ET/potential ET) on stomatal conductivity and leaf area index (LAI).

After an unstressed calculation of the photosynthesis, in a second round a scaling factor for water stress ( $\left.f_{\text {waterstress}}\right)$ is applied to the stomatal conductance (same for leaf and canopy) based on water in root zone relative to the wilting point ( 0.35 of max soil moisture content) and the uncritical water filling ( 0.75 of max soil moisture content); this enters the $\mathrm{C}$ assimilation rate (based on Farquhar or Collatz for C4) (Collatz et al., 1992) ; water stress of grass depends only on upper soil layer moisture.

Leaf photosynthesis based on (Collatz et al., 1991; Collatz et al., 1992). Potential photosynthesis is reduced by a factor that is linearly related to soil moisture availability (Cox et al., 1999).

Yes. Photosynthesis and actual evapotranspiration (AET) are calculated codependently by a coupled C and water flux module (Haxeltine et al., 1996). AET is constrained by available soil moisture and potentially limits photosynthesis via canopy conductance.

Leaf photosynthesis is related to soil moisture stress via actual canopy conductance, which decreases as soil moisture stress increases (Sitch et al., 2003).

Water stress is calculated from soil water content convoluted from a predefined root profile (PFT dependent). Then applied to reduction of Vcmax on photosynthesis.

Same as ORCHIDEE-2 except that is calculated from the 11 soil levels.

Photosynthesis is simulated using the Farquhar biochemical model and subsequent modifications (Farquhar et al., 1980; Bonan et al., 2011). Plant water stress is introduced by multiplying net assimilation with a correction factor that accounts for the root-zone integrated soil water potential and depends on two threshold parameters corresponding to the beginning of stomatal closure and to $50 \%$ stomatal closure.

Leaf photosynthesis based on modified Farquhar's model (Farquhar et al., 1980). Water related stress on photosynthesis is estimated as a function of soil moisture content in different soil layers (10 soil layers).

Water stress calculated based on root fraction for upper and lower vegetation, and the water stress factor was used to modify Vcmax in photosynthesis.

Water stress is calculated using volumetric water content, then applied to reduction of Vcmax. 
Table S7 Descriptions of stomatal conductance including (inc.) water stress in ecosystem models.

\begin{tabular}{|c|c|}
\hline Model & Stomatal conductance inc. water stress \\
\hline CABLE & $\begin{array}{l}\text { Photosynthesis (A) is represented following the Farquhar model (Wang and Leuning, 1998); stomatal conductance }\left(\mathrm{g}_{\mathrm{s}}\right) \text { is represented following (De Kauwe et al., } \\
\text { 2015; Medlyn et al., 2011). Water stress is represented by an empirical relationship based on soil texture and limits the slope of the coupled relationship between A } \\
\text { and } \mathrm{g}_{\mathrm{s}} \text { (Eqn. A19) (Wang et al., 2011). }\end{array}$ \\
\hline CLM45-ORNL & Ball-Berry model; stomatal conductance is affected by relative humidity; Ball-Berry intercept multiplied by water stress. \\
\hline DLEM & $\begin{array}{c}\text { Stomatal conductance is estimated as a function of maximum conductance regulated by a series of environmental limitations (Jarvis, 1976). Water stress is applied } \\
\text { to stomatal conductance according to vapor water deficit. }\end{array}$ \\
\hline DOS-TEM & Stomatal conductance is affected by evapotranspiration (estimated ET/potential ET). \\
\hline JSBACH & Stressed leaf stomatal conductance $\left(g_{\text {leaf,stressed }}=f_{\text {waterstress }} * g_{\text {leaf }}\right)$ scales up to canopy (canopy $=$ sum over three canopy layers each with distinct leaf area index). \\
\hline JULES & Stomata conductance is calculated following (Jacobs, 1994), and is indirectly modified by water stress due to scaling of leaf photosynthesis (Cox et al., 1999). \\
\hline LPJ-GUESS & $\begin{array}{l}\text { Coupled photosynthesis-stomatal conductance model, influencing intercellular } \mathrm{CO}_{2} \text {. Stomatal conductance at the canopy scale determined by solving for } \\
\text { photosynthesis and } \mathrm{CO}_{2} \text { diffusion gradient. When plant supply through soil water cannot meet estimated atmospheric demand, conductance is reduced. }\end{array}$ \\
\hline LPJmL-V3.5 & Actual canopy conductance under water stress is directly limited as a function of soil water supply. \\
\hline ORCHIDEE-2 & Stomatal conductance based on (Ball et al., 1987). Water stress applies on Vcmax but not directly on stomatal conductance. \\
\hline ORCHIDEE-11 & Same as ORCHIDEE-2. \\
\hline $\mathrm{T} \& \mathrm{C}$ & $\begin{array}{c}\text { Stomatal resistance is computed with a revised version of the Leuning stomatal model (Leuning, 1995; Mastrotheodoros et al., 2017). Downregulation of net } \\
\text { assimilation because of water stress affects stomatal conductance. }\end{array}$ \\
\hline TECO & $\begin{array}{l}\text { Stomatal conductance based on (Ball et al., 1987). A scaling factor is calculated using equations from (Lohammar et al., 1980) to incorporate vapor pressure deficit } \\
\text { (VPD) and soil moisture. Additionally, stomatal conductance is scaled by the size of the non-structural carbon (NSC) pool. }\end{array}$ \\
\hline TRIPLEX-GHG & Stomatal conductance based on Ball Berry model, canopy drought stress factor applied. \\
\hline VISIT & Stomatal conductance based on (Leuning, 1995) responds to VPD but not to soil dryness directly. \\
\hline
\end{tabular}


Table S8 Descriptions of scaling of photosynthesis from leaf to canopy in ecosystem models.

\begin{tabular}{|c|c|}
\hline Model & Scaling of photosynthesis from leaf to canopy \\
\hline CABLE & Two-leaf approach (sunlit and shaded) scaled by leaf area index (LAI). \\
\hline CLM45-ORNL & An exponential decrease of light into the canopy. To mimic the decrease of $\mathrm{N}$ into the canopy, the Vcmax also exponentially decreases into the canopy. \\
\hline DLEM & The photosynthesis at leaf level is scaled to the canopy through two-big-leaf model (De Pury and Farquhar, 1997; Dai et al., 2004). \\
\hline DOS-TEM & Big leaf approach. \\
\hline JSBACH & Canopy radiation model following (Sellers, 1985); Sum of stomatal conductance over all canopy layers (1-3) with local LAI (Kaminski et al., 2013; Knorr, 2000). \\
\hline JULES & $\begin{array}{l}10 \text { layer canopy with photosynthesis calculated for sunlit and shaded leaves, including sunfleck penetration. Leaf N decreases with canopy depth (Clark et al., 2011; } \\
\text { Harper et al., 2016). }\end{array}$ \\
\hline LPJ-GUESS & Big leaf approach. \\
\hline LPJmL-V3.5 & $\begin{array}{l}\text { Photosynthesis is estimated following big-leaf assumptions; actual fractional projective cover (FPC) by each plant functional type (PFT) is used for scaling to } \\
\text { grid-cell level. }\end{array}$ \\
\hline ORCHIDEE-2 & $\begin{array}{l}\text { Big leaf approach: an exponential decrease of light into the canopy. To mimic the decrease of } \mathrm{N} \text { into the canopy, the Vcmax also exponentially decrease into the } \\
\text { canopy with an asymptotic limit of } 30 \% \text { of Vcmax at top of canopy. }\end{array}$ \\
\hline ORCHIDEE-11 & Same as ORCHIDEE-2 \\
\hline $\mathrm{T} \& \mathrm{C}$ & $\begin{array}{l}\text { Photosynthetic Active Radiation (PAR) is explicitly transferred through vegetation using the two-stream approximation (Dai et al., 2004). Photosynthesis is upscaled } \\
\text { at canopy level assuming an exponential profile of leaf N content per unit of area and therefore photosynthetic capacity (Bonan et al., 2011). A "two big leaves" } \\
\text { scheme, where sunlit and shaded leaves are treated separately is used to compute net assimilation and stomatal conductance. }\end{array}$ \\
\hline TECO & Uses a "two big leaves" approach to represent sunlit and shaded leaves, which combine to determine canopy-level conductance, photosynthesis and transpiration. \\
\hline TRIPLEX-GHG & Big leaf approach. \\
\hline VISIT & Two-component (sun/shade) scheme by (De Pury and Farquhar, 1997): exponential light attenuation and beam/diffuse PAR. \\
\hline
\end{tabular}


Table S9 Descriptions of phenology in ecosystem models.

Model

CABLE

CLM45-ORNL

DLEM

DOS-TEM

JSBACH

JULES

LPJ-GUESS

LPJmL-V3.5

ORCHIDEE-2

ORCHIDEE-11

$\mathrm{T} \& \mathrm{C}$

TECO

TRIPLEX-GHG VISIT
Phenology

Leaf phenology is prescribed based on satellite observations (Zhang et al., 2003).

When a critical growing degree day sum (which is a function of mean annual temperature and accumulated soil temperature) is reached, leaf-on occurs over next 15 days. Senescence is initiated by critical day length and critical soil moisture.

Phenology is dependent on leaf status that ranges from 0 (dormancy) to 1 (summit). Monthly phenology value is set for each plant function type (PFT) based on satellite observations, through which daily phenology is interpolated.

Leaf phenology is influenced by temperature and the ratio between actual ET and potential ET.

Growth if sufficient soil water in upper layer \& temperature ( $\mathrm{T}$ air \& $\mathrm{T}$ ground $>4^{\circ} \mathrm{C}$ ); a constant growth rate $(0.09 /$ day) enters calculation of leaf area index $(\mathrm{LAI})$.

Cold deciduous: leaf loss and growth triggered by temperatures below and above a threshold ( $5^{\circ} \mathrm{C}$ for $\mathrm{C} 3$ and $\mathrm{C} 4$ grasses).

Fractional leaf coverage is updated daily for summer green trees and grasses. Leaf expansion begins when the daily mean temperature reaches $5^{\circ} \mathrm{C}$, after which fractional cover increases linearly with accumulated growing-degree days on a $5^{\circ} \mathrm{C}$ base (GDD5), achieving full cover at GDD5 $=200$ (trees) or 50 (grasses). Grasses can shed their leaves under conditions of severe water stress.

Daily phenology status of a PFT is the product of cold temperature, light, water, and heat stress limiting functions (Forkel et al., 2014).

Leaf onset is based on both temperature and soil water: When a given soil water and sum of temperature threshold is reached, the begin of season is triggered.

\section{Same as ORCHIDEE-2}

Phenology for grass is simulated considering four states: dormant, maximum growth, normal growth, and senescence. Transition between phenological phases are prognostic in the model and controlled by soil temperature, soil moisture and photoperiod length.

Phenology is represented by variations in LAI and transitions between growing and dormant stages. Growing stage is initiated by a certain number of growing degree days $>5{ }^{\circ} \mathrm{C}$.

Leaf senescence is induced by low soil moisture and low air temperatures (in fall months) following (Arora and Boer, 2005).

Temperature threshold was set for leaves dropping and reappearing based on PFT, drought phenology trigger was used for drought deciduous PFT.

Leaf onset of deciduous herbs is based on cumulative temperature (no explicit water effect). 
Table S10 Descriptions of mortality in ecosystem models.

\begin{tabular}{|c|c|}
\hline Model & Mortality \\
\hline CABLE & Fixed turnover. \\
\hline CLM45-ORNL & Leaf and fine root mortality is controlled by phenology \\
\hline DLEM & $\begin{array}{l}\text { Leaf mortality is dependent on the background mortality rate and plant phenology. In growing season, leaf turnover only determined by background mortality rate, } \\
\text { while in deciduous season, leaf turnover depends on phenology and background turnover rate. Sapwood and root turnover are dependent on plant function type } \\
\text { (PFT) dependent background turnover rate. }\end{array}$ \\
\hline DOS-TEM & Above and belowground litterfall are function of a calibrated litterfall rate, and the size of the vegetation $\mathrm{C}$ pool. \\
\hline JSBACH & $\begin{array}{l}\text { Fixed background mortality for grasses is } 1 \text { year. A constant shedding rate }(0.01 / \text { day) due to aging or if NPP=0 enters the calculation of leaf area index (LAI); The } \\
\text { mortality rate due to fire is at least } 0.006 / \text { year plus if enough litter is available as fuel at rel. humidity }<70 \% \text { over several weeks. }\end{array}$ \\
\hline JULES & Prescribed disturbance rate for each PFT. \\
\hline LPJ-GUESS & Shedding of leaves under very dry conditions; fire mortality, self-thinning, background mortality. \\
\hline LPJmL-V3.5 & Grasses are killed via heat stress, fire (not for the site simulations), or low growth-efficiency, and background mortality. \\
\hline ORCHIDEE-2 & $\begin{array}{l}\text { Leaf mortality is based on a double criteria: when temperature or soil water decrease the turnover rate increase. There is also a predefined leaf life span than rapidly } \\
\text { increase when leaves reach the critical leaf age. For other organs, then is a PFT dependent fixed turnover rate }\end{array}$ \\
\hline ORCHIDEE-11 & Same as ORCHIDEE-2 \\
\hline $\mathrm{T} \& \mathrm{C}$ & $\begin{array}{l}\text { Leaves are undergoing tissue turnover in function of tissue longevity and environmental stresses, i.e., drought and low temperatures. Other organ turnover is } \\
\text { dependent on fixed turnover rates. Complete mortality may only occur because of carbohydrate reserve depletion. }\end{array}$ \\
\hline TECO & Leaf senescence is induced by low soil moisture and low air temperatures (in fall months) following (Arora and Boer, 2005). \\
\hline TRIPLEX-GHG & Fixed turnover for each PFT. \\
\hline VISIT & Base mortality assuming aging-induced loss and seasonal leaf shedding, depending on PFT. \\
\hline
\end{tabular}


Table S11 Descriptions of soil hydrology in ecosystem models.

Model

CABLE

CLM45-ORNL

DLEM

DOS-TEM

JSBACH

JULES

LPJ-GUESS

LPJmL-V3.5

ORCHIDEE-2

ORCHIDEE-11

$\mathrm{T} \& \mathrm{C}$

TECO

TRIPLEX-GHG

VISIT
Soil hydrology

Soil hydrology is represented using a 6-layer soil column. Groundwater dynamics are represented using an unconfined aquifer that exchanges water with the soil column above. Runoff is generated from saturation and infiltration excess (Decker, 2015).

Multi-layer model governed by infiltration, surface and sub-surface runoff, gradient diffusion, gravity, canopy transpiration groundwater.

Hydrology is explicitly represented with a thickness of $3 \mathrm{~m}$ that is vertically separated across 10 different profiles. The scheme considers snowpack accumulation and depletion, surface evaporation, infiltration and surface runoff, drainage and recharge and aquifer storage. Soil properties including soil texture and bulk density control soil hydrological processes

Hydrology is explicitly represented with a thickness of root depth that is vertically separated across 15 layers. The scheme considers snowpack accumulation and melting, evaporation, infiltration and total runoff.

5 layer soil hydrology. Hydrology scheme based on Richard's equation (Hagemann and Stacke, 2015) for vertical movement of water in soils. All PFTs access same water bucket. Depths (m): 0.065, 0.254, 0.913, 2.902, 5.700. Grass depends only on upper soil layer moisture.

4 soil layers to $3 \mathrm{~m}$ depth, with vertical fluxes following Darcy's law (Best et al., 2011).

2.5-layer (up to $1.5 \mathrm{~m}$ soil depth) bucket model with constant hydrology considering snow pack, evaporation, transpiration, percolation, surface runoff, drainage, and baseflow runoff, all processes unrelated to soil temperature; soil consists in fractions of clay, sand and tilt; no between-patch transport (Gerten et al., 2004).

Five hydrologically and thermally active soil layers (0-0.2 m; 0.2-0.5m; 0.5-1.0 m; 1.0-2.0 m; 2.0-3.0 m). Explicit soil energy balance and soil hydrology see (Sibyll et al., 2013).

Hydrology is based on a surface and deep bucket. The surface bucket is created when the soil is partly filled by new precipitation arrives.

Hydrology is explicitly represented with 11 levels of increasing size with depth. The scheme consider diffusion, drainage and percolation process. Three different soil tiles are considered, to represent sandy, loamy and clay soils.

Vertical water content dynamics are solved using the one-dimensional (1D) Richards equation. Runoff generation is made possible via saturation excess and infiltration excess mechanisms. A free drainage condition is usually assumed at the bottom of the soil column. Soil layer number and depth is variable, typically

between 10 and 25 soil layers are used. Heterogeneity in soil texture and hydraulic properties can be accounted for.

Soil hydrology is determined for 10 soil layers (the first layer being $10 \mathrm{~cm}$ thick and the rest being $20 \mathrm{~cm}$ thick). Soil water content is calculated as budget between inputs (precipitation and infiltration) and outputs (runoff, evaporation, transpiration). Infiltration rates are determined by soil properties at each layer. Infiltration occurs sequentially from shallow to deep soil layers. Once all layers are saturated, water runoff occurs. The partitioning of transpiration loss from soil layers depends on the fraction of fine roots in layers. Soil surface evaporation is calculated based on (Sellers et al., 1996).

Based on bucket model, six soil layers.

Two soil water pools and snow: evapotranspiration based on Penman-Monteith, and ruonff based on bucket model. 
Table S12 Descriptions of surface energy budget in ecosystem models.

Model

CABLE

CLM45-ORNL

DLEM

DOS-TEM

JSBACH

JULES

LPJ-GUESS

LPJmL-V3.5

ORCHIDEE-2

ORCHIDEE-11

$\mathrm{T} \& \mathrm{C}$

TECO

TRIPLEX-GHG

VISIT
Surface energy budget

$L\left(T_{s}\right) E_{c}+H_{c}+L\left(T_{s}\right) E_{s}+H_{s}=R_{n}\left(T_{s}\right)-G$; where $L$ is latent heat for water vaporization, and is a function of surface temperature ( $\left.T_{s}\right), E_{c}$ is canopy evaportranspiration from wet and dry canopy, and dry canopy transpiration is calculated using two-leaf approach (Wang and Leuning, 1998), $E_{s}$ is soil evaporation, and is calculated following (Decker et al., 2017), $H_{c}$ is sensible heat flux from canopy and is calculated using Eqn. A16 of (Wang et al., 2011), and $H_{s}$ is sensible heat flux from soil and is calculated using Eqn. A24 of (Wang et al., 2011), $G$ is ground heat flux and is calculated using Eqn. A36 of (Wang et al., 2011). The energy balance equation was solved by iteration numerically, as described in (Wang and Leuning, 1998).

Plant function type dependent, but all PFTs share a single soil column (Oleson et al., 2013).

No

No

Fluxes are calculated for each tile in a grid cell but averaged over grid cell at the end of each time step and passed to atmosphere.

$C_{S} \frac{\delta T_{*}}{\delta t}=(1-\alpha) S W_{\text {down }}+\epsilon L W_{\text {down }}-\sigma \epsilon\left(T_{*}\right)^{4}-H-L_{c} E-G$; where $T_{*}$ is surface temperature, $C_{\mathrm{s}}$ is surface heat capacity, $S W_{\text {down }}$ and $L W_{\text {down }}$ are downwelling shortwave and longwave radiation, respectively, $\alpha$ is surface albedo, $\epsilon$ is surface emissivity, $L_{\mathrm{c}}$ is the latent heat of condensation of water at $0^{\circ} \mathrm{C}$, and $H, E$, and $G$ are sensible, latent, and ground heat fluxes, respectively (Best et al., 2011). Total surface evaporation consists of evaporation from canopy, soil surface, transpiration, and sublimation.

No

For each plant functional type albedo, and photosynthetically active radiation as a crucial input variable to light-limited photosynthesis are calculated (Sitch et al., 2003). Potential evapotranspiration based on Priestley-Taylor.

Whereas all the fluxes are calculated for each PFT, there in only on energy budget on the whole canopy. It is based on a full implicit scheme

\section{Same as ORCHIDEE-2}

Shortwave and longwave incoming radiation fluxes are explicitly transferred through vegetation. The energy, exchanges between the surface (soil and vegetation) and the planetary boundary layer are computed with a resistance analogy scheme accounting for aerodynamic, under-canopy and leaf boundary layer resistances, as

well as for stomatal, soil-to-root and soil-to-air resistances. The energy budget is solved at the hourly-scale with a fully implicit numerical scheme considering a single prognostic surface temperature.

Net available energy is calculated using transpiration, sensible heat, and latent heat of vaporization for water. Leaf temperature is modified using isothermal net radiation. Leaves lose heat based on leaf emissivity and air temperature.

Solar radiation is calculated within each vegetation layer using a two-stream approximation.

Net short- and long-wave radiation for evapotranspiration; snow-affected albedo; canopy and soil are calculated separately. 
Table S13 Descriptions of root profile and dynamics in ecosystem models.

\begin{tabular}{|c|c|}
\hline Model & Root profile and dynamics \\
\hline CABLE & The root biomass is a prognostic variable, but the relative fractions of roots in different soil layers (set by plant function type, PFT) do not vary over time. \\
\hline CLM45-ORNL & No dynamic root profile. An exponential profile fixed but PFT dependent. \\
\hline DLEM & No dynamic root profile. It is fixed in each layer but depends on PFT. \\
\hline DOS-TEM & No dynamic root profile. Root profile is fixed and defined by $10 \mathrm{~cm}$ increment. \\
\hline JSBACH & $\begin{array}{l}\text { Fixed rooting depth is calculated via (plant availiable soil water holding capacity) / (vol. soil field capacity) (Hagemann and Stacke, 2015). STU: } 1.03 \mathrm{~m}, \mathrm{KNZ} \text { : } \\
1.50 \mathrm{~m}, \text { SGS: } 0.70 \mathrm{~m} \text {. }\end{array}$ \\
\hline JULES & 4 soil layers to 3 meter deep. For grasses, $87 \%$ of roots are in the top meter. Root profile is constant. \\
\hline LPJ-GUESS & Root distribution per depth prescribed, $\mathrm{C}$ allocation to fine roots depends on water and $\mathrm{N}$ availability. \\
\hline LPJmL-V3.5 & Root profile is parametrised differently for $\mathrm{C} 3$ and $\mathrm{C} 4$ plants. \\
\hline ORCHIDEE-2 & No dynamic root profile. An exponential profile fixed but PFT dependent. \\
\hline ORCHIDEE-11 & Same as ORCHIDEE-2. \\
\hline $\mathrm{T} \& \mathrm{C}$ & $\begin{array}{l}\text { Root biomass is dynamic but root distribution with depth is prescribed. It follows an exponential profile where the root depth containing } 95 \% \text { of root biomass is a } \\
\text { model parameter. }\end{array}$ \\
\hline TECO & $\begin{array}{l}\text { Fine root proportions start with the following distribution: } 0-10 \mathrm{~cm}: 40 \% ; 10-30 \mathrm{~cm}: 40 \% ; 30-50 \mathrm{~cm}: 15 \% ; 50-70 \mathrm{~cm} \text { : } 5 \% \text {. Fine root distributions are dynamical, } \\
\text { varying with root growth and death in every soil layer. Root turnover is based on microclimatic conditions in soil layers. }\end{array}$ \\
\hline TRIPLEX-GHG & Root profiles are defined by the two parameter for upper and lower plants respectively. \\
\hline VISIT & No dynamic root profile, plant function type (PFT) based derived from (Zeng, 2001). \\
\hline
\end{tabular}


Table S14 Descriptions of grassland species in ecosystem models.

Model

CABLE

CABLE

CLM45-ORNL

DLEM

DOS-TEM

JSBACH

JULES

LPJ-GUESS

LPJmL-V3.5

ORCHIDEE-2

ORCHIDEE-11

$\mathrm{T} \& \mathrm{C}$

TECO

TRIPLEX-GHG

VISIT
Grassland species

Model does not include a dynamic vegetation model (i.e. changes in plant function type - PFT - fractions over time). For all the simulations here, a 100\% C3 fraction for STU and $100 \% \mathrm{C} 4$ fraction for KNZ and SGS were applied.

There is no calibration of model on the 3 sites. There are only 3 types of grassland: arctic C3, non-arctic C3 and C4. Non-arctic C3 and C4 phenology can be affected by soil moisture, arctic C3 only day length. Acclimation of photosynthetic parameters with 10-day running mean temperature.

Calibrated model at KNZ. Only C3 and C4 grassland type considered.

Calibrated model at STU using one-year data (2000). Big leaf model, no PFT explicitly represented.

C3 and C4 distribution according to site description: STU: C3: 0.9, C4: 0.1, KNZ: C3: 0.15, C4: 0.85, and SGS: C3: 0.3, C4: 0.7.

C3 or C4 grasses as described in (Harper et al., 2016).

No calibration of model on the 3 sites. $\mathrm{C} 3$ and C4 grasses, distribution calculated dynamically, based on bioclimatic limits and photosynthesis.

Grasses are distinguished by their photosynthetic pathway, $\mathrm{C} 3$ or $\mathrm{C} 4$.

There is no calibration of model on the 3 sites. There is only 2 types of grassland: C3 and C4. There is no distinction between climatic zones (in opposite to others PFTS). There is an adaptation of temperature dependent parameters (e.g. photosynthesis and respiration) to local long term mean annual temperature

Same as ORCHIDEE-2.

Key model parameters were manually adjusted and tested in a number of C3 and C4 grassland sites (Fatichi and Pappas, 2017), including the three sites used in this article. T\&C vegetation parameterization is location specific (not PFT), even though most of the parameters are shared across sites with the same vegetation category (e.g. grass).

Key model parameters were adjusted to reflect site level conditions and primary production.

No calibration of model on the 3 sites. Two types: C3 and C4 grasses.

No species-based parameter calibration: only C3 and C4 herbaceous types. Plant respiration temperature dependence, Q10, varies with local climatic condition, assuming plant acclimation. The model has been applied two grassland sites: alpine meadow of Qinghai-Tibetan Plateau and Mongolian semi-desert/grassland (results not published). 


\section{References}

Arora, V. K., and Boer, G. J.: A parameterization of leaf phenology for the terrestrial ecosystem component of climate models, Global Change Biology, 11, 39-59, 2005.

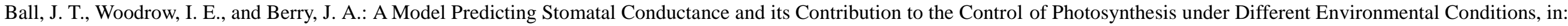

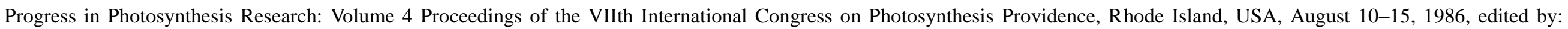
Biggins, J., Springer Netherlands, Dordrecht, 221-224, 1987.

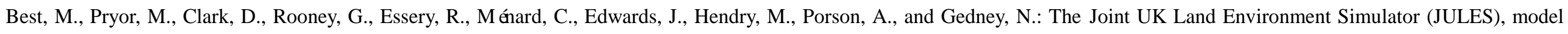
description-Part 1: energy and water fluxes, Geoscientific Model Development, 4, 677-699, 2011.

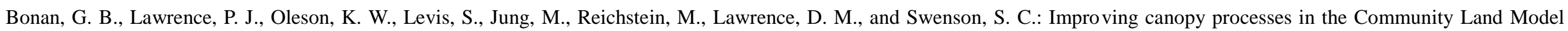
version 4 (CLM4) using global flux fields empirically inferred from FLUXNET data, Journal of Geophysical Research: Biogeosciences, 116,1 -22, 2011.

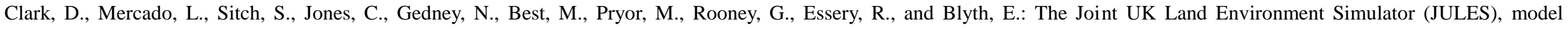
description-Part 2: carbon fluxes and vegetation dynamics, Geoscientific Model Development, 4, 701-722, 2011.

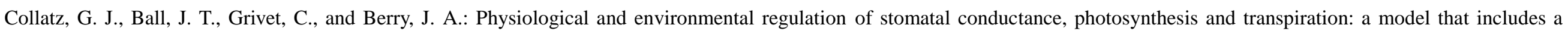
laminar boundary layer, Agricultural and Forest Meteorology, 54, 107-136, 1991.

Collatz, G. J., Ribas-Carbo, M., and Berry, J.: Coupled photosynthesis-stomatal conductance model for leaves of C4 plants, Functional Plant Biology, 19 , 519-538, 1992.

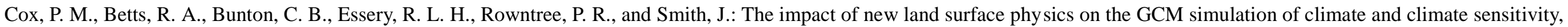
Climate Dynamics, 15, 183-203, 1999.

Dai, Y., Dickinson, R. E., and Wang, Y.-P.: A two-big-leaf model for canopy temperature, photosynthesis, and stomatal conductance, Journal of Climate, 17, $2281-2299,2004$.

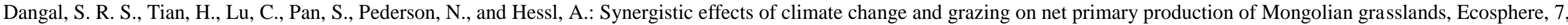
$1-20,2016$.

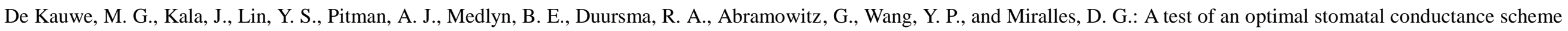
within the CABLE Land Surface Model, Geoscientific Model Development, 8, 431-452, 2015. 


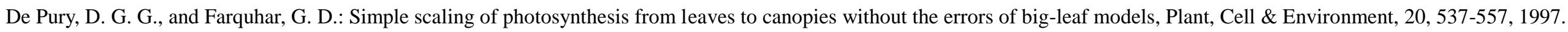

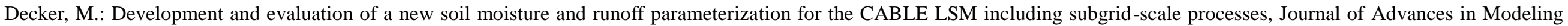
Earth Systems, 7, 1788-1809, 2015

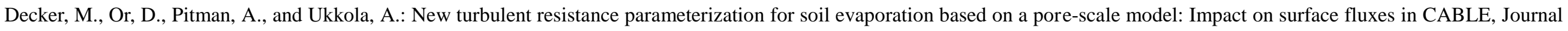
of Advances in Modeling Earth Systems, 9, 220-238, 2017.

Farquhar, G., von Caemmerer, S. v., and Berry, J.: A biochemical model of photosynthetic CO2 assimilation in leaves of C3 species, Planta, 149, 78-90, 1980.

Fatichi, S., and Pappas, C.: Constrained variability of modeled T:ET ratio across biomes, Geophysical Research Letters, 44, 6795-6803, 2017.

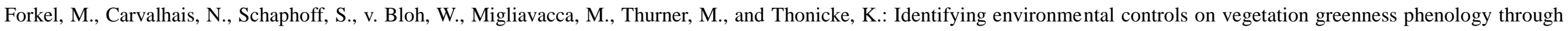
model-data integration, Biogeosciences, 11, 7025-7050, 2014.

Friedlingstein, P., Joel, G., Field, C. B., and Fung, I. Y.: Toward an allocation scheme for global terrestrial carbon models, Global Change Biology, 5, 755-770, 1999.

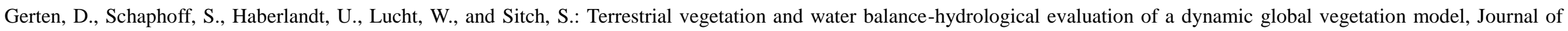
Hydrology, 286, 249-270, 2004.

Hagemann, S., and Stacke, T.: Impact of the soil hydrology scheme on simulated soil moisture memory, Climate Dynamics, 44, 1731-1750, 2015.

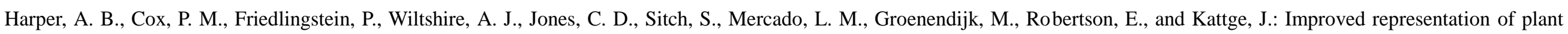
functional types and physiology in the Joint UK Land Environment Simulator (JULES v4.2) using plant trait information, Geoscientific Model Development, 9, 1-64, 2016.

Haxeltine, A., Prentice, I. C., and Creswell, I. D.: A coupled carbon and water flux model to predict vegetation structure, Journal of Vegetation Science, 7, 651-666, 1996.

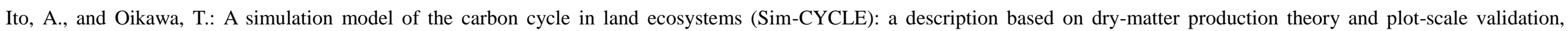
Ecological Modelling, 151, 143-176, 2002.

Jacobs, C. M. J.: Direct impact of atmospheric CO2 enrichment on regional transpiration, 1994.

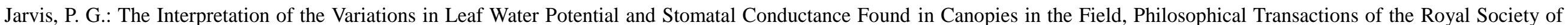
London. Series B, Biological Sciences, 273, 593-610, 1976 


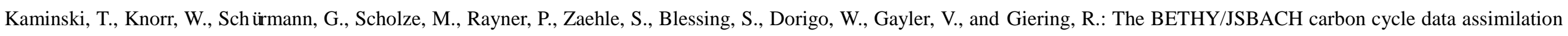
system: experiences and challenges, Journal of Geophysical Research: Biogeosciences, 118, 1414-1426, 2013.

Knorr, W.: Annual and interannual CO2 exchanges of the terrestrial biosphere: process-based simulations and uncertainties, Global Ecology and Biogeography, 9, 225-252, 2000.

Leuning, R.: A critical appraisal of a combined stomatal-photosynthesis model for C3 plants, Plant, Cell \& Environment, 18, 339-355, 1995.

Lohammar, T., Larsson, S., Linder, S., and Falk, S. O.: FAST: Simulation Models of Gaseous Exchange in Scots Pine, Ecological Bulletins, 505-523, 1980.

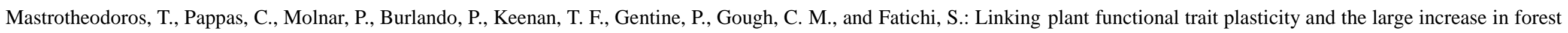
water use efficiency, Journal of Geophysical Research: Biogeosciences, 122, 2393-2408, 2017.

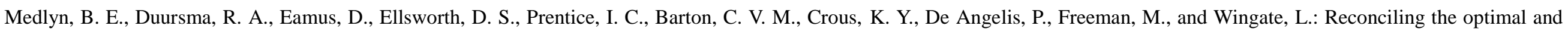
empirical approaches to modelling stomatal conductance, Global Change Biology, 17, 2134-2144, 2011.

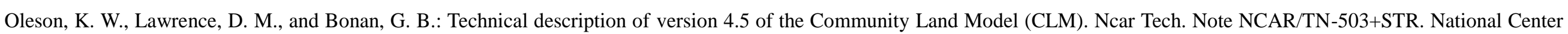
for Atmospheric Research, Boulder, Geophysical Research Letters, 37, 256-265, 2013.

Sellers, P. J.: Canopy reflectance, photosynthesis and transpiration, International Journal of Remote Sensing, 6, 1335-1372, 1985.

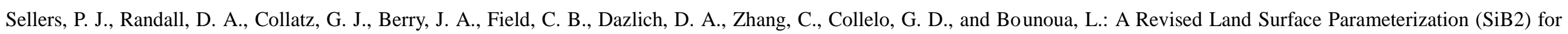
Atmospheric GCMS. Part I: Model Formulation, Journal of Climate, 9, 676-705, 1996.

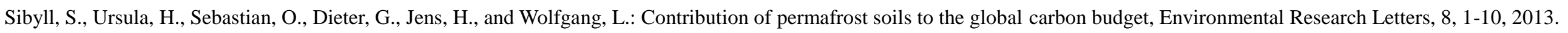

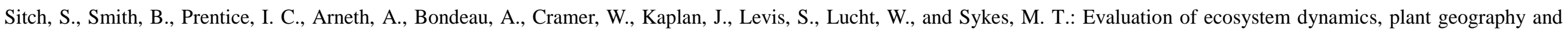
terrestrial carbon cycling in the LPJ dynamic global vegetation model, Global Change Biology, 9, 161-185, 2003.

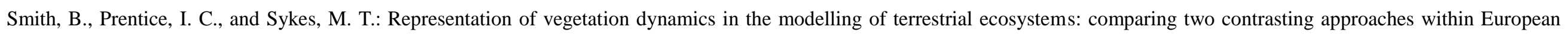
climate space, Global Ecology and Biogeography, 10, 621-637, 2001.

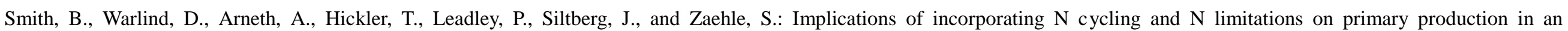
individual-based dynamic vegetation model, Biogeosciences, 11, 2027-2054, 2014. 


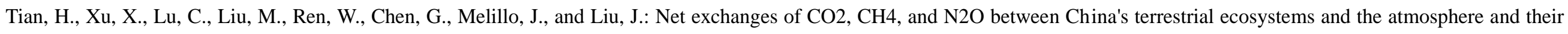
contributions to global climate warming, Journal of Geophysical Research: Biogeosciences, 116, 1-13, 2011.

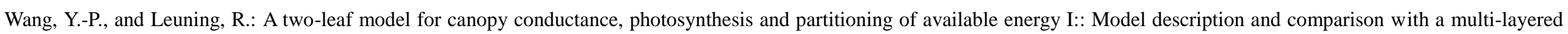
model, Agricultural and Forest Meteorology, 91, 89-111, 1998.

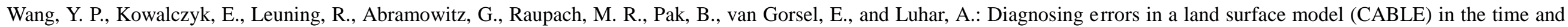
frequency domains, Journal of Geophysical Research: Biogeosciences, 116, 1-18, 2011.

Zeng, X.: Global Vegetation Root Distribution for Land Modeling, Journal of Hydrometeorology, 2, 525-530, 2001.

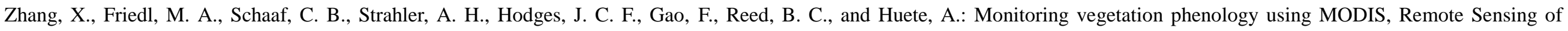
Environment, 84, 471-475, 2003. 